\title{
a junta da real fazenda em minas gerais e os projetos de abolição da circulação de ouro em pó (1770-1808): limites às reformas econômicas na colônia dentro da administração fazendária portuguesa ${ }^{\star}$
}

\begin{abstract}
Alexandre Mendes Cunha ${ }^{\star}$
Professor do Departamento de Economia e do Centro de Desenvolvimento e Planejamento Regional (Cedeplar), ambos da Universidade Federal de Minas Geais. Doutor em História pela Universidade Federal Fluminense.
\end{abstract}

RESUMO

$O$ presente artigo investiga a atuação em Minas Gerais da Junta da Administração e Arrecadação da Real Fazenda no que diz respeito aos diversos projetos apresentados a partir de 1770 ao Erário Régio em Lisboa versando sobre a abolição da circulação de ouro em pó. O artigo analisa o destaque da administração fazendária de Minas dentro do império, em particular por conta da importância assumida pelos tributos provenientes dessa região na estrutura das finanças do Estado português, e permite pensar, com base no tema específico da proibição da circulação de ouro em pó e da necessidade de introdução de larga soma em moeda metálica para as atividades comerciais na capitania, os limites às reformas econômicas na colônia impostos pela natureza em si do ordenamento colonial.

Palavras-chave: Administração fazendária. Erário Régio. Minas Gerais.

\begin{abstract}
This paper investigates the role of Board of the Royal Treasury (Junta da Real Fazenda) of Minas Gerais with respect to the various projects submitted from 1770 to the Royal Treasury (Erário Régio) in Lisbon, dealing on the abolition of the circulation of gold powder. The article analyzes the importance of the financial administration of Minas Gerais within the empire, in particular because of the place that fiscal gains from this region were acquiring in the structure of the Portuguese state finances, and to suggest, based on the specific issue of prohibiting the movement of gold powder and the need of introducing large sums of metal coins to sustain local commercial activity, the limits to economic reforms in the colony imposed by nature itself of the colonial order.
\end{abstract}

Key-words: Public finances administration, Royal Treasury, Minas Gerais.

* Submetido: abril, 2012; aceito: julho, 2012.

$\star \star$ Contato: Cedeplar-FACE-UFMG,Av. Antônio Carlos, 6627 - Belo Horizonte, MG/ CEP: 31270-901. A pesquisa contou com o apoio financeiro da FAPEMIG e do CNPq em diferentes estágios de sua realização.Email: alexandre@cedeplar.ufmg.br 


\section{Introdução}

Antes de iniciar a reflexão específica que o título do texto anuncia, faz-se necessária uma breve referência a uma ampla problemática, envolvendo uma alargada discussão historiográfica, sem a qual não seria possível efetivamente enunciar o problema que a análise das fontes primárias vai sugerir ao longo do texto.

Isso pode ser lido, em essência, como um dos panos de fundo centrais dos debates sobre o sentido da colonização na leitura de Caio Prado Jr. e, mais especificamente, na análise do antigo sistema colonial, nos termos propostos por Fernando Novais, no que diz respeito à natureza do empreendimento colonial em termos da extração de excedentes e da forma específica em que se dá a reedição e reprodução das condições para o funcionamento desse sistema, com grande destaque para a dimensão fiscal. Uma vez que o objetivo aqui é contribuir com novos elementos, a partir do aprofundamento da pesquisa documental, acerca de alguns detalhes pouco conhecidos da problemática geral da estruturação das finanças públicas no século XVIII em contraponto à questão das reformas econômicas, faz-se necessário refletir sobre o lugar de Minas na estrutura econômica e fiscal do Império português, assim como da especificidade da administração fazendária na capitania.

A passagem do século XVII para o XVIII ratifica de forma ampla dois processos que já se divisavam na segunda metade do século XVII: a viragem do império do Índico para o Atlântico e o reforço das relações de dependência em relação à Inglaterra (GODINHO, 1968; SERRÃO, 1998). O Brasil, que vai passando a ser efetivamente entendido como a joia da Coroa a partir de meados do século XVII, assume ao começo do século XVIII uma importância determinante nas receitas portuguesas, nas quais se destacam o ouro, e pouco depois os diamantes, mas também o tabaco, alvo de alguns dos mais rentáveis contratos em favor da Real Fazenda.

Dos efeitos diretos e indiretos desse influxo do ouro brasileiro na economia portuguesa destacam-se três aspectos em especial, de acordo com a síntese do tema que apresenta José Vicente Serrão (1998: 68): primeiro, a dinamização da atividade mercantil externa, uma vez que outros tantos países, atraídos pelo ouro que agora seguia a caminho do Reino, intensificavam seu comércio com Portugal; também os próprios 
lucros advindos do comércio colonial, com o Brasil, e dos circuitos internos, em particular nas atividades associadas ao comércio externo e colonial. Da mesma forma, o ouro fez aumentar a riqueza privada, tanto nas remessas diretas dos portugueses que aos milhares emigraram para as Minas quanto nos efeitos indiretos advindos do aquecimento geral da economia. Finalmente, pode-se destacar o efeito do ouro na disponibilidade de meios de pagamento ao exterior com a qual passa a contar Portugal e que tem impacto direto na pauta de importações, levando mesmo o país a abdicar de atividades produtivas a princípio menos rentáveis, substituindo-as por importações e reforçando os setores ligados à exportação que, em larga medida, era a reexportação de gêneros coloniais.

A contabilidade geral da riqueza produzida por Minas ao longo do século XVIII permanece ainda como um desafio à pesquisa, muito embora no curso dos últimos anos, graças aos trabalhos de Angelo Carrara, já seja possível avançar na direção de um primeiro desenho de conjunto robusto, crítico e confiável para este quadro geral. De forma ampla, no entanto, ainda há um bom caminho a ser percorrido, inclusive no que diz respeito à mensuração do impacto geral do ouro vindo do Brasil nas finanças portuguesas (CARRARA, 2004, 2006, 2007, 2009; COSTA, ROCHA e SOUZA, 2005).

Para além do impacto direto dessa riqueza vinda do Brasil, mensurável com precisão ou não, é preciso reconhecer, como se destacou acima, o impacto indireto que isso acaba por ter e os efeitos de encadeamento a partir daí produzidos. Não obstante, analistas variados destacam que esse impulso termina em boa medida por se autoconter na esfera mercantil, com desdobramentos para os sub-setores agrícolas, mas prejudicando mesmo a atividade industrial, uma vez que exatamente nesta área se intensificariam os interesses dos parceiros comerciais de Portugal. Acentuando o aspecto da subordinação aos interesses ingleses, em linha categoricamente marcada por Sandro Sideri ([1970] 1978), comentaria A. J. R. Russell-Wood:

(...) foi o ouro do Brasil que lubrificou o comércio atlântico português, financiando a administração do Império português do Atlântico Sul e permitindo a D. João $\mathrm{V}$ reinar como monarca absoluto. Também salvou Portugal de um problema mais grave, melhorando o equilíbrio da sua ba- 
lança de pagamentos com os parceiros comerciais europeus. Mas o preço exigido da Metrópole pela sorte inesperada e fortuita das descobertas de ouro do Brasil foi elevado. Os principais beneficiários do fluxo do ouro do Brasil foram outras nações, que não Portugal. Calcula-se que, entre metade e três quartos da totalidade do ouro que entrava no Tejo, ia para Inglaterra. Grande parte do restante foi gasto em projetos de gratificação pessoal, em vez de ter sido usado em investimentos a longo prazo no futuro da nação. O estímulo para a criação de empresas manufatoras embrionárias enfraqueceu (tendências que só se alterou nos anos 1770, com as iniciativas de Pombal) a transição de uma economia de troca para uma economia monetária foi desacelerada, a dependência da Inglaterra aumentou e o Estado deu-se ao luxo de atrasar a implementação de reformas extremamente necessárias (Russell-Wood, [1992] 1998: 222).

A partir de meados do século XVIII a prosperidade empurrada pelo ouro vai se erodindo. A retração que a partir daí, e de forma inalterável até o final do século, se faria sentir na produção aurífera mineira tem papel determinante; mas não convém afastar outros aspectos que pesam negativamente sobre a conjuntura econômica portuguesa, dentre os quais vale ao menos lembrar as decorrências econômicas do terremoto de 1755. Os caminhos buscados para alterar a conjuntura de crise que novamente fazia peso sobre as finanças portuguesas assumem forma em várias políticas públicas, instituídas, via de regra, no período do consulado pombalino. $\mathrm{O}$ esforço de carris protecionistas, que passa a ser assumido por Portugal, implicaria, entre outras áreas, esforços amplos no incentivo à produção industrial ou na reforma de instâncias centrais da administração. Não obstante, é o reforço do exclusivo comercial lusobrasileiro o que mais clara e intensamente se percebe como nota distintiva da condução econômica no período, como já bem demonstrou Fernando Novais (1979).

É fundamental perceber aí que a leitura da retração na produção aurífera mineira a partir de meados do século XVIII é algo que só se divisa na análise distanciada no tempo das séries históricas, não sendo sequer intuição por parte das autoridades metropolitanas ao começo da década de 1760, quando da criação do Erário. Vários anos se passariam com a consciência da decadência efetiva na produção aurífera, já se fazendo patente a administração local nas Minas, até que a orientação metropolitana recuasse na leitura de que a queda dos quintos devia-se 
a algo maior, mais grave e mais persistente do que o contrabando e a insubordinação fiscal do mineiro. Nesse sentido, ante o movimento econômico aqui sumariado, ficam claras a importância, a responsabilidade e as expectativas que pesavam sobre a quarta contadoria do Erário, responsável entre outras partes pela administração dos territórios da relação do Rio de Janeiro, onde então estavam todas as importantes áreas mineradoras do império. Importância, responsabilidade e expectativas que pesavam, não só sobre a repartição, mas sobre o seu titular, o contador-geral Luís José de Brito, que se ocuparia com a diligência da interlocução com a Junta da Real Fazenda de Minas Gerais, revelando substantivo conhecimento da realidade colonial.

Há nessa ampla problemática aqui referida um componente fundamental a nortear nossa reflexão, que é a especificidade das matrizes de ideias que informam as transformações na administração fazendária lusa no período e, de forma ampla, o próprio reformismo. Não há aqui como explorar todas as dimensões envolvidas, mas vale a menção a um aspecto em particular, que é tratado com o devido cuidado em outros de nossos estudos recentes. Trata-se da percepção de que o processo de centralização da administração financeira do Império, desenrolado a partir do período pombalino, conecta-se e se espelha em outros movimentos reformistas estabelecidos na Europa continental àquele tempo, nutrindo-se de matrizes de ideias variadas que incorporam desde o cameralismo à nascente economia política (CUNHA, 2011). Essa perspectiva de análise recoloca em registro mais amplo o tema do reformismo ilustrado, ajudando a perceber superposições diversas no discurso econômico e político dedicado à concepção e execução das reformas de Pombal até D. Rodrigo de Souza Coutinho (CARDOSO e CUNHA, 2012a; 2012b), permitindo estabelecer o interessante diálogo com a historiografia recente que vem ajudando a pensar o lugar do reformismo ilustrado enquanto conceito organizador das ações governativas na Europa do Sul e seus impérios atlânticos na segunda metade do século XVIII e primeiras décadas do XIX (PAQUETTE, 2008; 2009).

De fato é patente a importância da economia aurífera para as finanças portuguesas ao longo do século XVIII. Também é ponto bem explorado na historiografia o fato de que Minas Gerais vai se tornar uma das áreas com maior arrecadação fiscal no conjunto do Império no século XVIII e, inequivocamente, a mais importante da América portu- 
guesa $^{1}$. O que é ainda pouco conhecido e explorado nas análises é a percepção de que a importância fiscal de Minas Gerais, enquanto uma área que vai se dinamizando em termos de fluxos de comércio e de sua produção agropecuária, está associada a um conjunto de tributos, e não exclusivamente ao quinto, o que pode ser avaliado preliminarmente em se tomando comparativamente os valores somados de entradas e dízimos e de quintos ao longo do século XVIII ${ }^{2}$. Efetivamente, pode-se argumentar que o crescimento da arrecadação fiscal ao longo do século XVIII em Minas deveu-se mais ao crescimento da população e à complexificação da economia como um todo do que ao crescimento da mineração em exclusivo que, ao contrário, passa a se retrair de forma constante desde meados do século, com impacto direto (e angustiante à administração central) na arrecadação do quinto. $O$ problema então colocado é simples: o quinto do ouro era um tributo de natureza muito particular, devido diretamente à figura do Rei, e constituindo-se efetivamente em uma entrada líquida central às finanças públicas portuguesas na primeira metade do século XVIII que, à segunda metade, mesmo ante uma conjuntura de retração da atividade mineradora, o Erário tentaria a todo custo preservar. O crescimento da capitania ao longo do século e toda a pressão colocada desde o primeiro momento pelo Estado português para se controlar a mineração fizeram com que se desenvolvesse ali uma pesada máquina burocrática, que passou a absorver grandes somas de recursos e, ao final do século, basicamente fazia com que a arrecadação fiscal, mesmo que vultosa e gerando excedentes, estivesse pesadamente comprometida com as despesas correntes da própria capitania.

O tributo do quinto, de fato, seguiu direto para a metrópole por grande parte do século XVIII sem sequer entrar na "conta" geral da

1 Segundo as pesquisas de Angelo Carrara, mesmo havendo algumas lacunas importantes nos dados, é possível afirmar que entre 1700 e 1808 Minas Gerais fez remessas líquidas ao Erário da ordem de “41.676:471\$267, ou cerca de 6.783 arrobas de ouro, ou 100 toneladas de ouro", o que equivale basicamente a $70 \%$ do ouro brasileiro que deu entrada nos cofres do Estado no período (CARRARA, 2009: 61).

2 Os dados apresentados por Maxwell ([1973] 2001) no apêndice estatístico de sua obra clássica sobre Minas e frequentemente referidos na historiografia apresentam essas informações. Carrara (2009: 8) completa a série apresentada por Maxwell em um gráfico e discute especificidades e limitações das informações. Para os dízimos e entradas a fonte mais detalhada é Carrara (1999; 2007). 
arrecadação da capitania, de onde eram subtraídos os recursos necessários para se fazer jus às despesas correntes com as folhas eclesiástica, civil e militar, além de outras despesas com a administração.Após 1765, entretanto, autorizou-se que aquela que se configuraria como uma das mais significativas despesas a cargo da junta ao longo do século, a assistência à Demarcação Diamantina (que no período de 1765 a 1795 teve seu valor fixado em 200 contos de réis anuais), pudesse ser paga com o rendimento exclusivo do quinto, quando o rendimento da arrecadação corrente dos outros tributos não bastasse para tanto (CARRARA, 2009: 27-8).

Carrara discute com precisão como a partir de meados do século essa conjuntura fiscal foi se alterando, fazendo com que a partir da década de 1770

(...) os tributos cobrados e arrecadados diretamente pela Real Fazenda na capitania (dízimos e entradas, fundamentalmente) não tive[ssem] mais a capacidade de sustentar integralmente a assistência à Demarcação Diamantina. Nesse momento, cessaram as remessas de valores elevados para Lisboa, à exceção do subsídio voluntário, que entre 1757 e 1779 renderam à metrópole 1.033:705\$364 réis. Além disto, os quintos foram definitivamente incorporados à sua contabilidade (CARRARA, 2009: 53).

Há que se esclarecer que, ainda que a assistência ao Distrito Diamantino se desse como um empréstimo ou transferência posteriormente saldado diretamente junto ao Erário em Lisboa (ou seja, onerava o tributo do quinto em Minas), terminava por entrar da mesma forma, ainda que com atraso, nos cofres do Erário. O ponto é que o envio de remessas líquidas de recursos fiscais por parte da junta em Minas se viu enormemente constrangido da década de $1770 \mathrm{em}$ diante.A engrenagem colonial nas Minas desde então passaria a funcionar do ponto de vista fiscal com muito baixos resultados. É bem verdade, todavia, que gerava o suficiente, mesmo que acumulando dívidas de um ano para outro, para pagar toda a estrutura de estado instalada localmente, mas do ponto de vista das remessas líquidas o resultado passa a ser muito mais limitado do que antes.

Carrara, em seu desenho contábil geral para a capitania no período, não deixa de lembrar que "seja como for, mesmo no período de declínio da atividade mineradora, a capitania foi capaz de gerar um exceden- 
te fiscal diretamente enviado à Metrópole de cerca de 110 arrobas de ouro, entre 1758 e 1810" (2009: 61). O que me parece importante antepor a essa consideração é simplesmente reforçar o dado da mudança estrutural que ocorre na segunda metade do século, fazendo com que, mesmo havendo continuidade nas remessas líquidas, estas acabassem por ser irregulares e somassem valor que, mesmo não sendo desprazível, resultou, nesses mais de quarenta anos referidos, em valor equivalente ou inferior ao de remessas que eram atingidas em um único ano de períodos anteriores somente com o quinto ${ }^{3}$.

Dito isto, é possível agora introduzir o problema que será esmiuçado ao longo do texto: as tentativas de se compreender e de se buscar soluções para o problema da diminuição na arrecadação do quinto apontavam comumente para a questão da necessidade de melhoria das técnicas de mineração, introdução de moeda metálica na circulação interna da capitania e, no limite, de se deslocar o foco quase exclusivo da administração na tributação do ouro para se pensar os ganhos fiscais que seriam advindos da própria diversificação da economia como um todo. $\mathrm{O}$ problema nisso é que todas essas soluções exigiriam, em um primeiro momento ao menos, investimentos substantivos do Estado português e apontavam soluções que se relacionavam com a dinamização da economia local e com o aumento dos gastos com o aparato estatal local, o que não se traduzia de forma direta na ideia de extração de excedentes. Nesse sentido, a manutenção do discurso draconiano em relação ao quinto do ouro (e à derrama) e a aparente ignorância dos administradores coloniais em relação ao problema efetivo da queda na produção do ouro, sempre atribuindo publicamente o problema mais ao contrabando do que a qualquer outra coisa, é mais um caso da manutenção de uma estratégia de extração de excedentes e recusa ao investimento na economia local por conta de uma determinada concepção do papel da colônia dentro do "sistema colonial", do que o da incompetência dos administradores locais e da metrópole ou o desconhecimento da realidade e dos meios para se enfrentar o problema, como se demonstrará abaixo.

3 Comparando-se o valor de 110 arrobas de ouro para as remessas no período 17581810 com os dados citados na nota anterior, onde se estimam em não menos que 6.783 arrobas de ouro as remessas para o período como um todo, 1700-1808, percebe-se claramente a retração ocorrida na segunda metade do século. 
Antes, porém, vale comentar brevemente um problema que persistiu no orçamento da capitania ao longo da segunda metade do século XVIII e que tem interesse direto para a presente discussão. Trata-se do fato de que ao longo da segunda metade do século XVIII a junta em Minas vai custear as diferenças entre a quantidade de ouro enviado à Casa da Moeda no Rio de Janeiro e a quantidade de moeda provincial recebida em troca e transferida às intendências. Efetivamente, o problema da troca de ouro em pó por moeda metálica e, com isto, o vislumbre do problema geral da necessidade da supressão da circulação do ouro em pó, já seria atacado cotidianamente na administração fiscal das Minas, embora evidentemente em escala limitada, o que ainda assim não deixava de gerar impacto no orçamento da capitania ${ }^{4}$. A quantidade de moeda provincial que seria necessária para substituir o giro do ouro em pó na capitania ultrapassaria de fato, em muito, as capacidades orçamentárias das Minas, e exigiria um tipo de investimento direto por parte do Erário, o que faria alterar o sentido do fluxo de recursos do empreendimento colonial, não interessando em nada, portanto, à Metrópole.

\section{O Erário Régio, a Junta da Fazenda e a administração fazendária portuguesa}

A atuação em Minas Gerais da Junta da Administração e Arrecadação da Real Fazenda, ou simplesmente Junta da Real Fazenda, como acaba por ficar conhecida e se autodenominar, oferece a olhos do presente uma leitura substantiva de muito mais do que o detalhe da prática fiscal de então. O lugar dos tributos provenientes das Minas na estrutura das finanças do Estado português desde o início do século XVIII coloca, como já se referiu acima, destaque absoluto para a administração dessa região do império, e nesse sentido, amplifica a posição relativa da Junta de Minas entre suas congêneres. Não só por conta disso, que aproxima e sintoniza as expectativas por sobre a junta com as balizas políticas da administração central, mas também pela forma específica da sociedade, economia e cultura mineiras na segunda metade do século XVIII, o

4 Para a referência à série dos valores enviados à Casa da Moeda no Rio de Janeiro, veja Carrara (2009). 
estudo do organismo deixa ver, direta ou indiretamente, conjunto mais largo de questões. O estudo da Junta da Real Fazenda pode entrecruzarse, nessa perspectiva, a um conjunto variado de tópicos de análise, tais como: os limites da percepção da natureza específica e dos problemas próprios da economia mineira em fins do Dezoito; a importância dos círculos de poder localmente constituídos e o lugar de seus pleitos na condução das ações fazendárias; as próprias concepções de como se daria então o correto exercício tributário e, nisto, a leitura das leis, da justiça e do direito; o cruzamento dos interesses econômicos localmente constituídos e a burocracia montada para o exercício fazendário; entre outros mais pontos. Acrescente-se também que a segunda metade do século XVIII comporta acelerações e turbulências significativas na dinâmica econômica das Minas, o que de resto é também uma verdade para os mais diversos aspectos da sociedade urbana aí então constituída, coincidindo também, da mesma forma, o momento da organização mais elaborada do aparato governativo português nas Minas e o de uma instabilidade crescente no plano econômico e político local ${ }^{5}$.

O momento específico em que é criada a junta e os primeiros anos de seu funcionamento encerram assim, por si só, questões importantes em diversos níveis, o que constitui desafios para uma análise abrangente. Podem ser lembrados aí, por exemplo, a coincidência entre as reorientações administrativas, e, particularmente, na condução da ação fazendária, a partir do consulado pombalino, com o momento de rendimentos persistentemente decrescentes no quinto do ouro a partir de meados do século. Também não nos esqueçamos de sublinhar a influência (mesmo que atravancada de diversas formas) do espírito setecentista das luzes que alcança essa porção da América e, com isso, a força de novas ideias políticas no quadro internacional articulando-se, em alguma medida, a certo amadurecimento de uma percepção da dimensão local no horizonte de expectativas dos indivíduos que aí construíam suas vidas, como seria o caso de vários indivíduos ligados à ação fazendária nas Minas de então. Ou, por fim, o próprio aprofundamento

5 Os limites de escopo e de espaço ao presente texto impedem a exploração dos cruzamentos dos diversos caminhos historiográficos sugeridos neste parágrafo. Algumas das referências centrais às problemáticas aludidas, não obstante, podem ser indicadas aqui com proveito: Paula (2000), Figueiredo (1996 e 2005), Maxwell ([1973] 2001), Iglesias (1974), Melo e Souza (1982 e 2006) e Boschi (2002). 
da experiência urbana na organização social e dos desdobramentos de uma dinâmica econômica, o qual já articula espaços que em muito ultrapassam a mineração e que vão fazer dos pareceres nos quais os deputados da junta interpretam a realidade que lhes é apresentada e tentam nela intervir, um território para a leitura de um sem fim de problemas econômicos e políticos, entre o dito e o não dito, entre os acertos e os equívocos, e entre os variados interesses ali superpostos.

Talvez o caminho mais apropriado para captar os matizes próprios dessas questões seja a aproximação direta de algumas das temáticas centrais e recorrentes no exercício cotidiano da junta no século XVIII. Neste sentido, a análise de alguns dos pareceres produzidos pelo órgão permite uma boa introdução ao problema. Mais que isso, em se tratando de organismo largamente citado pela historiografia, mas que praticamente não mereceu ainda estudo mais sistemático de seu funcionamento $^{6}$, a exploração em si da documentação produzida pela junta já guarda grande interesse. Antes disso, entretanto, é importante apresentar com mais detalhes o contexto da criação do Erário Régio em Lisboa e da Junta da Fazenda em Vila Rica.

A criação do Erário Régio, por carta de lei de dezembro de 1761, muda efetivamente a paisagem da organização financeira no Estado português. Concebido enquanto instância unificada da contabilidade geral de receita e despesa do Reino e seus domínios funcionaria o erário como peça fundamental do processo de centralização política levado a cabo por Sebastião José de Carvalho e Melo, o futuro Marquês de Pombal, à época Conde de Oeiras. O reinado de D. José I, não obstante, assistiu desde seu começo, em 1750, a condução de uma série de medidas no sentido de melhorar a arrecadação dos direitos e rendas

6 Maxwell ([1973] 2001) foi um dos primeiros a dedicar atenção particular à Junta de Fazenda de Minas enquanto um órgão chave para a análise dos interesses políticos e econômicos que perpassavam a administração da capitania; todavia, o detalhe e a minúcia do funcionamento do órgão, incluindo sua posição na estrutura contábil e administrativa no Erário, não constituíram focos de destaque na análise desse autor. A leitura de Maxwell, entretanto, permanece fundamental para se compreender o conflito de interesses estabelecido ao redor da junta e as parcialidades envolvidas, em particular no que se relaciona à arrematação dos contratos. No que diz respeito ao funcionamento da escrituração e ordenamento contábil da junta, vale mencionar o trabalho de Carrara (2009), que oferece subsídios fundamentais para a compreensão do órgão. 
reais que se marcavam em particular pela dispersão em muitas repartições, pelos abusos dos oficiais do fisco e pelos vários atrasos nos depósitos desses direitos e rendas. Pode-se anotar, por exemplo, o alvará de maio de 1751, que extinguiu os ofícios de depositários da corte e cidade e criou a Junta de Administração dos Depósitos Públicos da Corte e Cidade de Lisboa, cumprindo dois objetivos fundamentais, quais sejam o de diminuir o atraso nos pagamentos e o de por em prática uma escrituração contábil que viabilizasse o controle das receitas e despesas por ali passadas. Poucos anos depois, em 1757, assiste-se à extinção de uma série de órgãos, anexando-se suas funções à junta referida acima. São suprimidos aí os depositários do juízo da Índia e Mina, ouvidoria da alfândega, capelas da Coroa, saca da moeda, direitos reais das sete casas, das capelas particulares, resíduos e aposentadoria-mór, assim como as tesourarias dos juízos dos órfãos (SUBTIL, 1998: 155). Este conjunto de mudanças já se daria ao tempo de Sebastião José de Carvalho e Melo, a frente da Secretaria de Estado dos Negócios do Reino ${ }^{7}$, mas também, e em particular, após o terremoto de 1755, que causou (entre muito mais, obviamente) a destruição do edifício do Terreiro do Paço onde funcionava a Casa dos Contos, o que contribuiu diretamente para a desordem nos serviços do órgão e, de alguma forma, precipitou na reorganização que se opera com o surgimento do Erário Régio.

A criação do Erário Régio insere-se assim nesse contexto de reestruturação administrativa do pós-terremoto e encontra-se em sintonia com um processo de centralização das finanças que guarda semelhanças com reformas absolutistas encampadas por outras monarquias europeias e sugere percursos de apropriação de matrizes de ideias econômicas, $\mathrm{o}$ cameralismo em particular (cf. CUNHA, 2011). Grosso modo, pode-se dizer que se a Casa dos Contos se limitava somente a confrontar as receitas recebidas e as despesas pagas pelos agentes do fisco, responderia o Erário Régio por substantiva inovação, na medida em que passa a ser agora o próprio Tesouro quem paga e recebe, buscando aprofundar o controle das contas e, ao mesmo tempo, evitar os descaminhos. O órgão se estruturava internamente em um arranjo hierárquico que tinha como

7 Sebastião José de Carvalho e Melo transita em 1756 da Secretaria dos Negócios Estrangeiros e Guerra, que ocupava desde o início do reinado de D. José I, para a Secretaria dos Negócios do Reino. 
figura máxima o próprio Secretário de Estado dos Negócios do Reino, no cargo de Inspetor Geral do Tesouro, "Lugar Tenente imediato à Real Pessoa de Sua Majestade". A ele seguia na hierarquia interna um tesoureiro-mor, cargo para o qual foi nomeado o negociante José Francisco da Cruz, e um escrivão, João Henriques de Souza, lente da Aula de Comércio e responsável pela função chave de elaborar um plano de escrituração do erário em partidas dobradas. $\mathrm{Na}$ sequência do organograma seguiam-se quatro contadorias, respondendo por partes distintas do império, tendo à frente um contador geral, auxiliado por quatro escriturários. Havia ainda três tesoureiros gerais, auxiliados cada um por um escrivão, sendo um para a receita e despesa dos ordenados, outro para os juros e o terceiro para as tenças assentadas nos almoxarifados do Reino. Completavam esse desenho inicial do erário um porteiro e quatro contínuos. No total eram 33 funcionários, número que foi sendo aumentado essencialmente em função de novos escriturários e supranumerários, o que viria a perfazer um total de 203 funcionários em 1827 (MOREIRA, 1977: X-XII).

Existe um hiato entre a instrução que determina a criação da Junta da Real Fazenda em Minas Gerais e a instalação definitiva do órgão. Neste sentido, é preciso não perder de vista o processo de transição entre a Provedoria e a Junta da Fazenda, uma vez que a efetivação prática do novo órgão levaria vários anos ${ }^{8}$. Após a criação do erário foram estabelecidas tesourarias ou juntas da fazenda nas várias capitanias brasileiras, e com ritmos diferentes em outras partes dos domínios portugueses. A Junta da Fazenda em Minas foi instituída em 1765; as instruções específicas para o seu funcionamento só foram recebidas, entretanto, alguns anos depois, em 1769. Porém, não tendo esta junta alcançado os resultados específicos objetivados pelo Erário Régio em termos da organização das contas em Minas, ela seria novamente instituída e regulada com base na carta régia de sete de setembro de 1771, passando a funcionar nesse novo modelo entre fins de $1772 \mathrm{e} o$ ano de 1773 (MAXWELL, [1973] 2001: 63) ${ }^{9}$. De forma concreta, no transcurso entre 1765 e 1772 o que funcionou mesmo foi uma provedoria da fa-

8 Essa discussão do funcionamento da administração das finanças em Minas Gerais desde a instalação da Junta da Fazenda até a Tesouraria Provincial está desdobrada em Cunha (2012).

9 AHU, Minas Gerais, cx. 101, doc. 37. 
zenda com certa reorganização de funções e cargos, ainda que se autointitulando de Junta da Real Fazenda em certos documentos. Data de sete de setembro de $1771 \mathrm{a}$ ordem para essa instituição definitiva da junta, o que se associa diretamente, enfim, ao provimento de meios para uma organização contabilística moderna das finanças na capitania, qualificando-se na transferência de Carlos José da Silva para o cargo de escrivão da junta. Por sua vez, são suprimidos os lugares da provedoria logo depois, em ordem datada de 14 de setembro do mesmo ano (VASCONCELLOS, 1994: 100).

Era função da junta a administração, arrematação e arrecadação de todos os direitos e subsídios reais da capitania, assim como a provisão das serventias dos ofícios da fazenda e a expedição das folhas dos ordenados eclesiásticos, civis e militares, além daquelas de natureza extraordinária. Cumpre destacar a importância logo reunida pelo novo órgão por conta da responsabilidade de arrematar os contratos da capitania, antes da alçada direta do Conselho Ultramarino, em Lisboa (MAXWELL, [1973] 2001: 63-4). Ao mesmo tempo em que a criação do erário representa um movimento de centralização, que em tudo se associa à centralização política processada por Pombal, há também um movimento contrário no seio disso que, antes de constituir uma contradição, é exatamente uma das novas orientações gerais da política pombalina e das estratégias para assegurar as bases de manutenção de tal poder. Refirome a uma dispersão na autonomia decisória para uma série de questões que antes se concentravam em tribunais metropolitanos e que desde então caberiam a instâncias diversas pelo conjunto do império. A responsabilidade pela arrematação dos contratos nas capitanias do além-mar, transferindo para as juntas da fazenda atributos exclusivos do Conselho Ultramarino, é ótimo exemplo disso ${ }^{10}$.

A Junta da Fazenda, no que diz respeito à sua organização interna, era presidida pelo governador e capitão-general da capitania e completada por quatro vogais: um juiz e um procurador dos feitos da fazenda, um tesoureiro geral e um escrivão. $\mathrm{O}$ juiz dos feitos até 1775 seguiu

10 Todavia, não se deve deixar de marcar bem aqui que essa era, como se disse, uma maior autonomia "relativa", sendo que existia toda sorte de limitações às atribuições do órgão, como por exemplo, na ausência de liberdade para a alocação das despesas ou de criação de novas receitas, e no reforço de uma estrutura que fazia convergir agora ainda mais pesadamente o centro decisório para a metrópole, no erário. 
sendo o provedor, sendo a partir dá substituído nessa posição pelo ouvidor de Vila Rica; o procurador da fazenda, por sua vez, na extinta provedoria, era cargo ocupado por um bacharel natural do país ${ }^{11}$, mas a partir de 1774 o cargo passou a ser atribuição anexa ao lugar de intendente do ouro, da Casa de Fundição de Vila Rica (VASCONCELLOS, 1994: 100-1). Sujeita à junta estava uma contadoria geral, que efetivamente era, tal qual se dava no Erário Régio, a repartição encarregada do conjunto das operações cotidianas do órgão em termos de recebimentos e pagamentos. Na contadoria geral da Junta da Real Fazenda em Minas tinham assim lugar como funcionários pela altura de 1780, segundo a informação de José João Teixeira Coelho, intendente do ouro de Vila Rica entre 1768 e 1779, quatro escriturários contadores, quatro escriturários ordinários, três ajudantes, sendo um fiel do tesoureiro geral, um porteiro e um contínuo (COELHO, 1994: 63). Ao começo do século XIX, seguindo os dados de Diogo Pereira Ribeiro de Vasconcelos, tesoureiro da intendência do ouro de Vila Rica, contavam-se seis escriturários contadores, dez ajudantes, porteiro e contínuo (VASCONCELLOS, 1994: 101). Havia ainda como oficiais da junta um tesoureiro, com seu respectivo escrivão, e um solicitador, com meirinho e escrivão (COELHO, 1994: 63).

No que diz respeito diretamente aos homens que ocuparam os lugares de deputados na junta pode-se logo qualificar a proximidade de intenções com o provimento de cargos no erário e, em larga medida, com orientações próprias do período pombalino. Trata-se da importância concedida aos homens de negócio na administração das finanças do Reino e o incentivo ao recrutamento das elites locais. Kenneth Maxwell insiste nesse aspecto, argumentando que assim como na "Real Fazenda [Erário Régio], as Juntas da Fazenda das capitanias deviam recrutar funcionários entre os 'homens abastados e prudentes' locais, especialmente os mais ricos comerciantes, que deviam ser estimulados mediante a fixação de soldos atraentes a colocar sua perícia comercial a serviço dos negócios públicos" (MAXWELL, [1973] 2001: 63).

Este é sem dúvida um aspecto fundamental a ser destacado. Tanto nas juntas quanto na administração central, no erário, a figura dos co-

11 O inconfidente Cláudio Manuel da Costa, por exemplo, pretendeu o cargo, mas não o conseguiu. 
merciantes é presença marcante desde o primeiro momento. Há, entretanto, algumas questões ainda mais instigantes no desenho montado pela administração portuguesa que não figuram na análise de Maxwell e que, em particular em relação a Minas, assumem grande interesse para a compreensão do processo como um todo. O primeiro ponto é a estabilidade dos funcionários-chave para a efetiva condução do trabalho contábil-fiscal (tesoureiro e escrivão, fundamentalmente) em seus postos. No caso do escrivão há ainda a especificidade crucial do privilégio e o interesse de prover nessas funções indivíduos que haviam passado pela Aula de Comércio e que, nessa condição, estavam efetivamente habilitados para o exercício da escrituração com partidas dobradas. Há ainda um outro aspecto, em nada evidente, mas que nos parece haver sido também objeto de atenção das autoridades metropolitanas quando da provisão dessas posições-chave e que diz respeito a um certo entremear de indivíduos no qual contava o conhecimento técnico, mas também o conhecimento da realidade local, e que era base fundamental para o funcionamento da administração da fazenda real e o diálogo efetivo entre as juntas e o erário. Nesse sentido, justifica-se aqui uma ligeira exploração de dois nomes-chave na administração fiscal das Minas de um lado e do outro do Atlântico, ambos havendo permanecido décadas a frente de seus postos: Carlos José da Silva, na Junta da Fazenda, e Luís José de Brito, no Erário.

Carlos José da Silva era homem de confiança direta do nome central à administração fiscal das Minas no Erário, o titular da Contadoria Geral da relação do Rio de Janeiro, da África Oriental e da Ásia portuguesa, Luís José de Brito, que, por sua vez, tendo sido provido no cargo quando da instalação do erário, em 1762, permaneceria no exercício de suas funções por décadas, até a virada do século seguinte. É sob a supervisão direta de Luís José de Brito que é admitido, em 1763, na função de segundo escriturário, Carlos José da Silva. Algum tempo depois, em 1767, já sabedor das minúcias de seu ofício e do funcionamento específico do órgão, Carlos José da Silva é despachado para a função de escriturário contador à Junta da Fazenda do Rio de Janeiro que àquele ano se estabelecia ${ }^{12}$.Volvidos mais alguns anos e já reguladas as confusões iniciais que também a Junta do Rio enfrentou, Carlos José seria o es-

12 AHTC, Erário Régio, livro 461, p.15 e livro 4068: 62. 
colhido então para a função principal na Junta de Minas que se queria ver definitivamente instalada ${ }^{13}$.

O que é interessante destacar aqui, entretanto, é justamente o nome, quase nunca referenciado em nossa historiografia, de Luís José de Brito, que em seus despachos e pareceres no erário daria provas de conhecimento profundo e concreto da realidade das Minas. Parece-nos que, se por um lado fazia sentido, dentro da engenharia da reestruturação das finanças públicas portuguesas, empreendida por Sebastião José de Carvatho e Melo, mandar dissolver e refundar a Junta da Fazenda em Minas por esta não atender às exigências modernas da escrituração contábil fundamentais ao erário e designar, assim, alguém vindo do Reino com formação técnica adequada para assumir o posto, como foi o caso de Carlos José da Silva; por outro lado, fazia também sentido que o titular da contadoria geral encarregada do controle da área mais rica do Império, literalmente a galinha dos ovos dourados de El Rei, possuísse, para além do conhecimento técnico pretendido, também o conhecimento efetivo de Minas Gerais e das peculiaridades daquele contexto. A primeira exigência só se podia atender àquele momento no contexto português a partir da recorrência a um experimentado homem de negócio; já a segunda, acompanhando a tendência de que pouco a pouco ia se apresentando em relação à administração do ultramar, podia se dar com a recorrência a um natural do país, como foi o caso do santista Alexandre de Gusmão, secretário privado de D. JoãoV e negociador do Tratado de Madrid, ou ao menos por alguém com permanência efetiva naquele espaço, como se deu em outros tantos casos, por exemplo, na nomeação de Luís Diogo Lobo da Silva para o Conselho Ultramarino depois de seu tempo como governador em Minas. Sem dúvida, a favor de Luís José de Brito, pesava tanto a coincidência de ser, segundo Jacome Ratton, um dos poucos negociantes do Reino acostumados ao tempo à contabilidade por partidas dobradas, o que o habilitava a uma daquelas posições-chave na fundação do erário, quanto o fato, que passou despercebido em nossa historiografia, de ser ele natural de Minas Gerais, o que o conectava perfeitamente à contadoria que deveria haver com o controle da fazenda nessa região do Império ${ }^{14}$.

13 AHTC, Erário Régio, livro 4068: 62.

14 Para uma exploração das trajetórias e o aprofundamento dos dados biográficos de Luís José de Brito, Carlos José da Silva e outros envolvidos na administração da fazenda em Minas Gerais no período, veja Cunha (2007). 


\section{Os pareceres da Junta da Fazenda ao Erário Régio}

Em sete de outubro de 1790, depois de descoberta e devassada a conspiração de 1789 , mas ainda antes da sentença final aos implicados, determinava a Rainha, por meio de seu real erário, que a Junta da Fazenda em Minas se pronunciasse acerca "dos meios, e modos mais suaves de se ressarcirem sem maior vexame dos povos o prejuízo que a Real Fazenda experimenta atualmente na arrecadação do Quinto do Ouro destas Minas" (RAPM, 1901:153). A demanda é clara: ressarcir o prejuízo, sem maior vexame dos povos. Obviamente, a "fórmula" de taxar sem o maior vexame os povos é peça retórica comum nesse tipo de correspondência, mas assume no momento em questão maior importância. Pode-se considerar que há aí certa mudança no tom da demanda, ao menos se compararmos essa solicitação ao endurecimento de posições que caracterizava as instruções dadas por Martinho de Melo e Castro ao governo de Luís Antonio Furtado de Mendonça, oVisconde de Barbacena, que assume seu posto em julho de 1788 .

Um panorama relativamente intrincado vinha aí pressuposto. $\mathrm{O}$ conjunto de certezas manifestas, aos olhos da coroa, acerca da predisposição dos naturais das Minas à fuga da tributação, da questão do contrabando como um dos problemas centrais, assim como da plena viabilidade de se fazer completar o déficit acumulado no quinto pelo recurso à derrama, estava bem repisado no texto de Melo e Castro que serve de instrução ao governo de Barbacena nas Minas. O questionamento metropolitano apresentado acima expressa, entretanto, um momento de hesitação (mesmo que bastante parcial) acerca dessas certezas e de verificação das estratégias a serem seguidas então, uma vez que persistia o decréscimo dos quintos, e já estando desde março do ano anterior, 1789, suspensa a derrama.

A decretação da derrama representava, dentro das ambições dos inconfidentes mineiros (essa era a expectativa confessada), a melhor oportunidade para se deflagrar o movimento, um tanto como estratégia para ganhar apoio de parcela ampla da população das Minas. Dessa forma, tanto a pergunta de Sua Majestade como a resposta da junta se davam em contexto no qual o tema da derrama já havia se deslocado, ao menos momentaneamente, do repertório principal de ações fiscais, colocando na ordem do dia a pacificação dos ânimos. Pesava, não obs- 
tante, uma vez mais a preocupação com o continuado decréscimo nos quintos, e o desafio que se apresentava era encontrar forma adequada para o ressarcimento desses prejuízos sem com isso contribuir para aumentar a inquietude nas Minas. Trata-se, dessa maneira, de uma conjuntura na qual, da parte da administração metropolitana, aponta-se a direção do reconhecimento de que se está diante de um ambiente pouco propício para uma medida de força no plano fiscal, ainda que não se afastasse das concepções gerais acerca do problema que se apresentava; e que, da parte do poder local, encerrava-se um contexto no qual ainda se fazia necessária a demonstração de que a Inconfidência era um evento restrito, e não uma conspiração com amplas teias percorrendo o interior das elites mineiras, o que deveria ser expresso com renovado empenho de lealdade à Coroa e efetiva demonstração desse compromisso no parecer da junta. Tudo isso era agravado, por exemplo, pelo fato de que um dos condenados na devassa, o ouvidor Tomás António Gonzaga, havia sido membro da junta, trabalhando direta e proximamente com três dos então vogais que assinam o parecer.

O documento em resposta à solicitação da Rainha concentraria, como de costume, a opinião coletiva da junta, mas também os ecos das consultas preliminares às câmaras da capitania sobre o referido tema. De maneira geral, o que se lê é uma defesa da manutenção do status quo da administração fazendária, insistindo-se que "o atual método das Casas da Fundição estabelecido pela Lei de três de Dezembro de 1750 era o mais justo, e tinha sido o mais bem aceito dos Povos" (RAPM, 1901:153). O diagnóstico das causas na retração dos rendimentos dos quintos é, da mesma forma, o reforço da fincada interpretação metropolitana, qual seja, do contrabando como maior problema. A resposta ao contrabando já qualificara, vale dizer, desde muito tempo e com particular reforço no período pombalino, a importância das forças militares na capitania. Não obstante a esse reconhecimento dos descaminhos do ouro como problema central, não se esquivam os deputados da junta de mencionar, ainda que sem insistir em mais considerações a esse respeito, que são bem conhecidas as "causas fisicas", uma vez que "não há quem deixe de notar a diferente riqueza, e rendimento da antiga mineração feita nos álveos dos rios hoje exauridos"; mas seria "em muito grande parte" a causa do problema "o extravio do ouro em pó que sai da Capitania antes de ser quintado para os portos do mar". A solução apontada seria 
então a de um reforma de alguns aspectos da Lei de 1750, mais especificamente o ponto relativo à circulação de ouro em pó na Capitania, sendo a sua proibição a pretendida chave para a retração do contrabando, e, nisso, o aumento da arrecadação. São discutidos então os procedimentos específicos para a condução do ouro às casas de fundição, bem como a multiplicação de tesoureiros menores para ampliar as teias da tributação; mas sem bem deixar de considerar a importância e a forma como se daria a substituição do ouro em pó que circulava nas Minas por moeda provincial "de forma que o comércio interior não fique embaraçado" (RAPM, 1901). Não há, todavia, uma leitura que vá além disto, considerando minimamente a importância do comércio interno para a força daquela economia, dos efeitos de encadeamento aí pressupostos, e nisto, uma leitura das possibilidade de tributação que poderiam daí advir ${ }^{15}$.

Outras proposições mais específicas, entretanto, seriam ajuntadas ao parecer, respeitando essa busca pelas soluções ao decréscimo da arrecadação, e se apontam aí, por exemplo, medidas como a supressão de alguns cargos e a anexação de outros, resultando em economia nos ordenados,

15 Obviamente, tal ordem de considerações não constituiria exatamente o que se esperaria ouvir em resposta à demanda tão específica: cobrança de dívidas. Mas é necessário lembrar que essas ideias não eram estranhas ou distantes da administração local, e tampouco seriam sugestão nova à administração central, como dá provas a exposição que Dom Rodrigo José de Meneses, Conde de Cavaleiros, governador de Minas entre fevereiro de 1780 e outubro de 1783, que envia ao ministro Melo e Castro em 4 de agosto de 1780, e na qual se lê: "Outro da mesma espécie, bem digno da Régia reflexão, que pede maior combinação de ideias, seria o estabelecimento de um fundo por conta da Fazenda Real, de onde se emprestasse ouro aos mineiros, que dele precisassem. As utilidades que resultariam de semelhante estabelecimento são inumeráveis. A primeira que se oferece, e quanto a mim, a menos considerável é oito, ou nove por cento que se poderia lucrar de interesse do dinheiro, atendendo que nas compras fiadas que faz o mineiro de escravos, e gêneros lucra o vendedor vinte e cinco, e trinta, que o dinheiro contato reduzirá a dez, ficando assim o comprador ganhando cinco ou dez, e o giro do comercio muito mais ativo. A segunda que observo, donde derivam tantas utilidades que a imaginação as não pode todas compreender, é que com esta facilidade aumentará o numero, e força das lavras, por consequência os quintos: a importação dos escravos, por consequência o valor dos contatos da Costa da África, a importação dos tabacos naqueles portos, por consequência a agricultura da Bahia; a dos negros neste e no Rio de Janeiro, e por consequência os contratos de entrada deles na cidade e alfândega. O numero de indivíduos, por consequência o consumo de sustento, e vestuário por consequência dos gêneros produzidos, e fabricados no Reino, por consequência o rendimento do contrato das entradas desta capitania, e o das alfândegas da Bahia, Rio de Janeiro, Lisboa e Porto" (RAPM, 1897: 317-8). 
ou ainda na tributação diferenciada dos bens de luxo nos registros. Só uma voz nesse documento expõe-se à dissonância ampla: a do tesoureiro geral, Afonso Dias Pereira, que não por acaso era um negociante importante da capitania e que vem a propor tanto uma mudança no valor em réis da oitava de ouro quanto a mudança mesmo no regime dos quintos, reeditando a capitação, com valor específico a ser pago por cada negro ou mulato.

O documento apresenta mais uma série de detalhes, assim como, na sequência ao parecer conjunto, a íntegra do testemunho individual do escrivão, do provedor da fazenda e intendente do ouro e do tesoureiro, o que em si faz do documento peça de interesse, uma vez que a recuperação desses pareceres individuais não é ordinária. Interessa primeiro, no entanto, a análise desse alinhamento da junta em um diagnóstico geral, determinando a continuidade e o acerto dos métodos já estabelecidos, e o significado disso.

A resposta central seria então, como se disse, a proibição da circulação do ouro em pó, alterando o disposto no alvará de três de dezembro de 1750 , uma vez que "só por meio da geral proibição nesta, e nas mais capitanias do giro, e uso qualquer de ouro em pó debaixo de graves penas substituindo-se lhe o da moeda provincial de prata e cobre se poderá conseguir que ele seja apresentado nas casas de fundição sem extravio para ser quintado nelas conforme o referido método" (RAPM, 1901: 154). Fica aí exposta a contraparte da questão: a proibição da circulação do ouro em pó exige sua substituição por moeda provincial. A junta avança em seu raciocínio:

Proibindo rigorosamente o giro de outro em pó é certo que se faz necessário suprir a falta dele, de forma que o comércio interior não fique embaraçado. Para este fim pareceu que em todas as casas de fundição que presentemente existem, ou nas que ficarem existindo, (...) se hajam de fundir barras de menor peso que fossem ao menos de dez oitavas, instituindo-se para o troco muito em lugar de ouro em pó moeda provincial de prata e cobre com diminuição do valor, e com proibição de correr fora das capitanias onde o giro do ouro era permitido, visto que a proibição deste deve também ser geral em todas elas (RAPM, 1901:155-6).

Dois são os problemas práticos a se enfrentar então. Primeiro, a quantidade de moeda provincial que se deveria colocar à disposição nas 
Minas para a troca pelo ouro em pó; segundo, como se procederia essa permuta por todo o território. Para o primeiro ponto, o resultado apresentado é genérico, sem explicitar a base do raciocínio, simplesmente referindo-se a uma cifra de algo como seiscentos ou quatrocentos contos, a serem divididos por cada uma das intendências do ouro estabelecidas na capitania. Mas vale considerar o que esse montante representaria então. Seiscentos contos equivaliam a 97 arrobas e 42 marcos de ouro, ou seja, quase a pretendida cota anual das 100 arrobas, valor superior à própria receita da capitania no período (cf. CARRARA, 2009; GUIMARÃES, 2006). Ainda assim, o rendimento do quinto verificado no ano anterior ao parecer da junta havia sido de 41 arrobas e 34 marcos e, no mesmo patamar, o do ano de 1791, que ao momento em que o parecer da Junta se encerrava somaria 41 arrobas e 28 marcos, equivalente ao rendimento do quinto (RAPM, 1901 964-5). Ante essa ordem de valores não parece mesmo que fosse fácil seduzir a administração central com uma proposição como essa.

O outro problema era, como se adiantou, a forma para se colocar em circulação esse dinheiro amoedado pelas Minas. Neste sentido, depois de distribuídos pelas respectivas intendências do ouro, essa era a proposição, os tesoureiros de cada uma delas ficariam incumbidos da permuta. Todavia, acrescentava o parecer:

(...) como aos sobreditos tesoureiros não é possível pela distancia das casas às povoações e territórios minerais de cada comarca servirem a toda a permutação necessária, pareceu que se deviam estabelecer tesoureiros menores em todos os arraiais, e mais paragens onde se (...) reconheçam precisos (...), e recebendo de prêmio três por cento a vista das partes do total que permutarem quando se liquidar a sua conta na intendência (...), e para que mais facilmente hajam de se oferecer os ditos tesoureiros devem ter estes alguns privilégios segundo Vossa Majestade for servida concederlhes (RAPM, 1901:156).

Ainda que não implicasse diretamente um gasto em salários para a coroa, o plano obviamente promoveria uma substantiva ampliação dos indivíduos inseridos nos quadros da fazenda nas Minas, e que seriam "havidos por oficiais das mesmas casas [intendências] como são os atuais fiéis" (RAPM, 1901: 156). Tal medida não deveria parecer também muito interessante aos olhos da administração central, uma vez que já 
se fazia claro àquele momento o quanto pesava e consumia das rendas reais na capitania a manutenção da ampla estrutura burocrática que ali se desenhou. A longa digressão do deputado da junta, o escrivão Carlos José da Silva, acrescida logo depois do parecer conjunto, refletia particular atenção justamente à possibilidade de economia nas despesas da real fazenda com a redução de ordenados nas intendências, assim como a extinção de alguns cargos. (RAPM, 1901: 161-2).

A opinião contrária ao diagnóstico conjunto pode ser recolhida, por sua vez, na digressão individual de Afonso Dias Pereira, tesoureiro geral da junta. Declara esse deputado acerca de todas as medidas colocadas pelo coletivo da junta que "tudo isso parecia conveniente, mas eu ponderando algumas oposições que se seguem ao exposto, considero não poder ter o efeito que se pretende" (RAPM, 1901:172). Primeiro, ataca o lugar comum de que a falta nos quintos procede toda do extravio, no que reflete que "estamos vendo que a falta que há do presente para o dito real quinto é de sessenta arrobas pouco mais ou menos, no que se pode ver, não procede tudo do extravio, pois para tocar ao mesmo quinto vinte arrobas é necessário extraviar cem arrobas, e para as sessenta que vemos faltam era preciso extraviar trezentas arrobas, no que bem se mostra não poder ser" (RAPM, 1901: 172-3).

Coloca então dois pontos polêmicos como solução: primeiro o de "por-se o ouro a mil e quinhentos reis a oitava, seu verdadeiro valor com o que me persuado ficar mais seguros o real quinto, e o mesmo povo mais satisfeito assim mineiros com os roceiros, negociantes e todos mais"; e, segundo, considerando "haver nesta capitania para cima de duzentos mil negros, e mulatos, forros e cativos, estes a oitava de ouro cada um, só duzentas mil perfazem a quantia de cinqüenta arrobas" (RAPM, 1901: 173). A mudança no método de arrecadação operada pelo alvará de 1750 encontrava sintonia direta com a orientação política e econômica pombalina, havendo resultado, na época de sua assinatura, significativa oposição, particularmente verbalizada por Alexandre de Gusmão, idealizador do método de capitação posto em prática em 1735 e então em vigor (FIGUEIREDO, 2005: 28). Mas esse método, que consagra o restabelecimento das casas de fundição e institui a derrama, foi se convertendo progressivamente em uma razão inquestionável de Estado, no que qualifica a polêmica à qual se expunha o tesoureiro com sua sugestão e chama atenção a este personagem, 
que será ainda contemplado com mais detalhes em outro momento do presente texto.

É sugestivo ver ainda que, mesmo considerando que são os faiscadores velhacos e ladinos, no que se faria muito dificil sujeitá-los a fazer entrar todo o ouro em pó nas casas de fundição, não hesita esse deputado em situar o problema noutro nível, tirando do contrabando o peso do problema. Isso introduz por sua vez a questão do estado de decadência em que as Minas se encontravam. O provedor da fazenda Francisco Gregório Pires Bandeira também se referiria a isso em seu parecer, com o seguinte raciocínio:

Estas Minas devem se considerar como um corpo político, e assim como os mais corpos tem esta seu princípio, aumento, estado, e declinação, circunstâncias estas que se devem considerar atentamente para se lhe poder aplicar o remédio à proporção do estado em que se acha (RAPM, 1901:167).

Há que se destacar, todavia, não a percepção da efetiva retração na produção aurífera, o que não deveria escapar à compreensão de ninguém que vivesse e estivesse atento ao cotidiano das Minas de então, como era bem o caso dos deputados da junta, mas o espaço restrito para a exposição de divergências à ordem de Sua Majestade. Ante uma ordem específica e um momento político delicado como era aquele do pós1789, a melhor alternativa aos vogais da junta seria mesmo repisar argumentos já aprovados anteriormente, sem grande polêmica, ainda que lateralmente explicitasse algo das particularidades locais. Essa cautela que se converte em estrita atenção à pergunta da Rainha é o que bem se lê na exposição de Carlos José da Silva, quando este comenta que a cota de cem arrobas foi prometida "em tempos florescentes, e abundantes da capitania, e franqueza das lavras sem reserva, como hoje sucede pelo contrario em muitos lugares (...), mas eu só devo ocorrer conforme a citada ordem em pinçar o que será mais útil aos reais interesses com a conservação desta capitania" (RAPM, 1901: 161).

Mais interessante e curioso, todavia, não é continuar na leitura dos pormenores do texto, e sim perceber como esse diagnóstico apresentado pela junta se insere em uma longa sequência de argumentos coincidentes, que, começando bem antes desse parecer, só encontraria resolução efetiva muito depois, reeditando com pouca variação o mesmo 
diagnóstico e propondo os mesmos medicamentos. Alguns momentos dessa recorrência podem ser pinçados em documentação variada.

\section{A questão da proibição da circulação de ouro em pó}

Lê-se, em representação copiada pela Contadoria geral do território da relação do Rio de Janeiro, África oriental e Ásia portuguesa, relativa a Minas Gerais e datada de 31 de julho de 1783, ainda ao tempo do governo de Dom Rodrigo José de Meneses, que "o remédio mais eficaz que ocorre para se não extraviar o ouro é dar a providência que ele não corra mais como moeda em todos os Estados Ultramarinos" ${ }^{\prime 16}$. Ou ainda, considerando que:

(...) proibido o giro de ouro em pó, os mineiros logo que queiram fazer uso do que extraíram o devem levar à junta da intendência do real quinto da sua comarca, e apresentando-os deduzir esta os quintos de Sua Majestade e as quatro partes que restam ou satisfazer-lhas em moeda provincial se assim os pedirem aqueles, regulada cada oitava depois de quintada a 1500 rs., para com o dito prodevirem (sic.) pagarem as suas dívidas menores e acudirem as suas despesas diárias. Ou metendo-lhas em borrachas ou cartuchos, que as partes devem fazer à proporção do ouro que pretenderem quintar, entrega-los a seus donos para com eles fazerem os seus pagamentos $(\ldots)^{17}$.

A quantidade de moeda provincial que se faria necessária introduzir nas Minas com a proibição da circulação do ouro em pó é também considerada, propondo-se, entretanto, valores muito distantes do intervalo de quatrocentos a seiscentos contos referidos em 1791.Dessa forma, "para que não faltem as espécies de que dependem os tratos e os contratos, parece que se deve determinar à casa da moeda desta cidade para que no primeiro ano remeta para a junta da fazenda de Vila Rica o valor de cem contos de réis em moedas de todos os metais, para se dividirem pelas quatro comarcas à proporção da sua grandeza e da sua

16 AHTC, Erário Régio, Livro 4066: 89.
17 AHTC, Erário Régio, Livro 4066: 94. 
população" 18 .Também se insiste no ponto da economia que se faria com a abolição das casas de fundição, que bem poderiam ser substituídas pelas câmaras de cada uma das vilas na função de permuta do ouro em pó. Pontos coincidentes seriam atacados na já referida exposição de Dom Rodrigo José de Meneses acerca do estado de decadência das Minas, redigida logo ao primeiro ano de seu governo:

Uma tão grande desordem me obriga a pensar, que ainda no caso que Sua Majestade, por algumas razões a que não pode chegar a minha compreensão, não houvesse por bem estabelecer a Casa da Moeda com as circunstâncias, que tenho indicado, e fosse servida conservar as da Fundição, que se acham estabelecidas, sempre seria útil ao Seu Real serviço, e bem comum dos vassalos abolir total e indistintamente a circulação do Ouro em pó, ordenando que este passasse imediatamente da mão do mineiro para as casas de fundição, onde fosse permutado em barras, mandando recolher todo o que circulasse; e pagando com moeda provincial, não da que se acha estabelecida, que apenas aqui chega do Rio de Janeiro, logo desaparece; mas da que passo a indicar (RAPM, 1897:322).

Os passos que indicaria, depois de uma digressão sobre os vícios na circulação monetária na Europa, e das práticas do aumento do valor nominal e diminuição do toque das moedas, o que expõe o Reino a perdas consideráveis, sendo tudo embasado em "um maduro exame de todas as circunstâncias, que o acompanham, e todas as faces com que minha compreensão o pode considerar", eram que se deveria mandar circular nas Minas, "em lugar do ouro em pó, moeda provincial de prata e cobre, que não tivesse valor intrínseco mais que metade ou a terça parte daquele que representasse", do que decorreriam possibilidades à real fazenda de "lucrar sobre os vassalos desta capitania dois milhões" ao fazer-lhe este "grande beneficio" (RAPM, 1897: 323).

Mais de uma década antes, não obstante, o tema de se proibir a circulação de ouro em pó nas Minas já havia sido contemplado em altas instâncias deliberativas do Estado português. Sendo notórios os "inconvenientes que a experiência tem mostrado que se seguiram de correr nas Minas o ouro em pó, depois que cessou a necessidade que fez essa permissão indispensável ao tempo em que se promulgou a Lei de 3 de

18 AHTC, Erário Régio, Livro 4066: 89. 
dezembro de 1750" buscou-se uma solução ao problema, que vai exposta em assento dado na Secretaria dos Negócios do Reino em 26 de julho de 1770 , e que consiste na proibição do giro do ouro em pó e na exposição de uma série de providências em atenção ao beneficio do "comércio interior das mesmas Minas" ${ }^{19}$. Vale a exposição circunstanciada. A primeira providência que caberia a Sua Majestade autorizar era:

Ordenar o mesmo Senhor, que toda a moeda das outras capitanias do Brasil, ou seja de ouro, ou de prata, ou de cobre, tenha giro nas Minas, abolindo inteiramente os chamados vinténs de ouro, que contém intoleráveis fraudes e comum prejuízo ${ }^{20}$ (RAPM, 1897).

O tema da quantidade de moeda que deveria ser posta em circulação é discutido em seguida, sendo decidido que se deveria "mandar introduzir em cada uma das comarcas das Minas Gerais 50 ou 60 mil cruzados (20 a 24 contos de réis), de moeda de prata e ouro, de todo o dinheiro provincial que correr no Brasil, remetendo-se também algum cobre" ${ }^{21}$. Indicava ainda a mesma quantia a ser remetida para Goiás e 40 mil cruzados para Paracatu.Todavia, calculando o valor de cada uma das quatro comarcas a 60 mil e somando o valor indicado para Paracatu, tem-se 112 contos de réis, ou seja, pouco mais do que o proposto em 1783, mas também muito abaixo do valor sugerido em 1791.

O documento refletiria ainda a respeito da distribuição das casas de fundição sobre as áreas minerais, sugerindo coisas como a transposição da casa de fundição de Minas Novas para Rio das Contas ou a criação de uma outra em Paracatu, com "a menor despesa que couber no possível", o que reflete visão ampliada do território e da dinâmica dos sucessos ou retração dos novos descobrimentos, alvo das maiores atenções dos governadores e capitães generais das Minas. A preocupação era também, não obstante, a economia nos gastos com a administração da capitania, e sendo que essa passava necessariamente pelo redimensionamento dos salários, tem lugar uma proposição nesse sentido, que ao mesmo tempo bate em outra tecla, consubstanciando ação marcada-

\footnotetext{
19 AHTC, Erário Régio, Livro 4070: 70.

20 AHTC, Erário Régio, Livro 4070: 70-1.

21 AHTC, Erário Régio, Livro 4070: 70-1.
} 
mente pombalina: a abertura da administração colonial às elites locais, em processo que é fundamental mesmo para a compreensão da constituição e funcionamento da Junta da Fazenda e ao qual ainda se dará destaque aqui. Diz o texto:

(...) abolindo-se nesta [a pretendida casa de fundição de Paracatu] e nas mais Minas os intendentes que vão do Reino com excessivos salários, e provendo-se esses lugares em pessoas das mesmas terras, onde há homens de probidade que estando em suas casas servirão por $600 \$ 000$ em lugar dos 4 mil cruzados [1.600\$000] que vencem os atuais intendentes. E os fiscais podem ficar no mesmo preço, fazendo-se os intendentes trienais e os fiscais anuais. Os escrivães da receita sendo também da terra podem vender $400 \$ 000$, e os da forja $300 \$ 000$, o meirinho $100 \$ 000$, o escrivão do meirinho outros $100 \$ 000$, o tesoureiro outros $400 \$ 000$ sendo também da terra.

Esse conjunto de pontos destacados já é suficiente para anotar uma visão aprofundada do quadro geral das Minas àquela altura. Sendo que o tema da proibição da circulação do ouro em pó, que reapareceria depois em demandas variadas vindas das Minas, já estaria contemplado e recomendado na própria Secretaria dos Negócios do Reino. Na reunião ocorrida no Palácio de Ajuda estavam presentes, assinando o documento, os seguintes nomes: Dom João, Arcebispo Regedor; Conde de Azambuja; Conde de Bobadela; Francisco Marcelino de Gouvêa;João Pereira Caldas; José Ricalde Pereira de Castro; Bartolomeu José Nunes Cardoso Giraldes; Joaquim Ignácio da Cruz; Luiz Diogo Lobo da Silva e Manoel da Fonseca Brandão. Ante a lista dos nomes, é possível vislumbrar não só a importância do colegiado ali reunido como ter clareza sobre as matrizes do conhecimento específico da situação das Minas, patente no texto. Nesse tema em particular dois nomes se destacam. O de José Antonio Freire de Andrada, o segundo Conde de Bobadela, que exerceu interinamente, em nome de seu irmão Gomes Freire de Andrada, primeiro Conde de Bobadela, o governo da capitania entre 1752 e 1758 (isso formalmente, mas ainda permanecendo como espécie de lugar-tenente do irmão em Minas até 1760); e o de Luiz Diogo Lobo da Silva, que permaneceu no governo das Minas entre 1763 e 1768 (BOSCHI, 2002: 101).

Há boas evidências para creditar, não obstante, ao segundo, importância maior na concepção das medidas propostas. Da atuação de Luís 
Diogo Lobo da Silva no governo nas Minas merece destaque sua preocupação com os limites territoriais da capitania, particularmente ao sul, na divisa com São Paulo, no que se traduz o interesse pelos novos descobertos e a ampliação das áreas minerais na capitania. Atento ao alvará de três de dezembro de 1750 fez cumprir ao longo de seu governo uma derrama que reparou os prejuízos de 13 anos no rendimento dos quintos. Com isso, sua leitura do contrabando como problemachave permitiu avançar a conexão entre a permitida circulação de ouro em pó e as facilidades ao descaminho do metal. Dessa forma, imporia a uma região de novos descobrimentos auríferos no sudoeste da capitania, a partir de um bando de 24 de setembro de 1764, a permuta de todo o ouro em pó em circulação.Tal ação abre clara exceção ao alvará de 1750, assim como introduz exatamente o mesmo tipo de compreensão do problema que parece nortear o assento dado na Secretaria dos Negócios do Reino em $1770^{22}$. No bando, lê-se o seguinte:

Ordeno a todos os moradores deste arraial de São Pedro de Alcântara, e Almas, os de Santa Ana, e de São João de Jacuí mineiros; e negociantes de todos os seus distritos, que presentemente se acharem com ouro em pó ou moeda de ouro cunhada de qualquer valor, venham perante mim apresenta-la no preciso termo de três dias sendo moradores de algum dos ditos arraiais; ou no de oito sendo das suas circunferências, onde pelo escrivão que serve na vedaria, e fiel do tesoureiro da Fazenda Real desta capitania com intervenção do Dr. Desembargador Provedor da mesma se permutará todo a barras de ouro fundido, e moeda provincial de prata, continuandose a mesma permuta pelo tempo adiante encarregada ao fiel, cabo de patrulha, ou outra qualquer pessoa eleita deste fim, e não comparecendo dentro do mencionado termo qualquer pessoa que for achada com o dito ouro em pó, ou em moeda de ouro cunhada dentro dos registros ficará sujeito às penas estabelecidas (...) (RAPM, 1901: 140).

Dois outros momentos dessa trajetória de proposições coincidentes ao longo do tempo, apontando agora para o seu desenlace no século

22 Não é demais ponderar que a participação ativa de Lobo da Silva nesses tipos de deliberações, informadas por sua experiência de governo da capitania de Minas e, logo antes, na de Pernambuco, devem ter lhe valido algum tempo depois a nomeação como membro do Conselho Ultramarino, em 27 de janeiro de 1773. (BOSCHI, 2002: 102) 
XIX, devem ainda ser destacados dentre outras entradas ao tema. Antes disso, porém, cabe avaliar que a recorrência de temáticas não se deve a um só fator. Há razões que podem ser lidas na prática administrativa de então, instituída dentro de uma ordem centralizada (ainda que com ampliação da participação local), o que contribui para a restrição do espaço ao dissenso e valoriza a recuperação das ideias e perspectivas já referendadas pela vontade real, até como forma de alinhamento desses setores locais incorporados/cooptados na máquina administrativa. Há que se ver também, por outro lado, de que modo um caso como o da proibição da circulação de ouro em pó encontra limites evidentes para sua resolução imediata, particularmente por conta do dispêndio que teria a coroa com a ação, o que termina por fazer com que as disposições tendessem a não resultar em ações efetivas. $\mathrm{O}$ caso em questão é eloquente nesse sentido, uma vez que, em cada reapresentação da medida, mais profundamente já se faria sentir a crise da mineração, e que, por outro lado, ainda maior seria a população, e indiretamente o mercado interno da capitania, sendo assim maiores as necessidades de meio circulante para substituir o ouro em pó. Ou seja, cada vez que a solução era novamente apresentada, seria cada vez mais caro o medicamento e cada vez mais breve a promessa de sobrevida, suprimindo, obviamente, muito do interesse régio de solucionar a questão por essa via.

Os dois outros momentos aludidos, que são 1803 e 1808, de alguma forma podem ser entendidos como reforçadores da ideia de que o problema da proibição da circulação do ouro em pó e sua substituição por moeda corrente foi progressivamente deixando de ser solução para a fuga do metal precioso sem o pagamento do tributo devido para se converter em uma necessidade objetiva do funcionamento do mercado, dado que em que se fez cada vez mais evidente a efetiva exaustão do ouro no padrão de exploração adotado, tornando-se mais e mais marginal o peso desse tributo dentro do conjunto das receitas.

O alvará de 13 de maio de $1803^{23}$ é a primeira peça legal que sus-

23 O alvará de 1803 é em vários aspectos o documento mais completo e ambicioso acerca da reforma na administração fiscal nas Minas em todo o período. No entanto, não há espaço aqui para uma discussão pormenorizada do documento.Vale, entretanto, referenciar que o texto base do documento legal deve-se a Manuel Ferreira da Câmara que, por sua vez, baseia suas proposições acerca da forma pela qual se deveria proceder a troca de ouro em pó por moeda em suas observações 
pende a circulação de ouro em pó nas Minas, assim como institui a criação das casas de permuta, que restituiriam, pelo metal em pó, moedas, barras fundidas ou "bilhetes de permuta". O alvará previa ainda a criação: de um órgão, onde seriam recolhidos o ouro e diamantes apreendidos pela fiscalização, que se chamaria Real Caixa de Economia de Minas e Fundições; de companhias de mineração, que deveriam funcionar como sociedades por ações e que teriam preferência nas grandes minas; assim como de uma Casa da Moeda, que se estabeleceria em Vila Rica e que absorveria ainda a do Rio de Janeiro em suas atribuições (SALGADO, 1985: 92-3). A lei acabaria, entretanto, por ficar sem efeito, particularmente devido à ausência de meios para executar o plano em sua amplitude e, em específico, para se por em curso a substituição do ouro em pó por moeda corrente. Comenta sobre isso o Barão de Eschwege, em sua "Notícia e reflexões estadísticas da província de Minas Gerais", que "este alvará fundado sobre verdadeiros princípios montanisticos, mas o plano, é tão gigantesco, e em muitos princípios impraticável no Brasil de modo que conhecendo-se as dificuldades de pô-lo em prática, ficou sem efeito, entretanto sobre ele se deve formar uma lei mais econômica, e adequada para os estados do Brasil" (RAPM, 1901: 754).

Em 1808, entretanto, é que teriam lugar medidas que efetivamente alterariam a circulação monetária nas Minas. Não só um documento, mas um conjunto de decretos, todos dados já depois da chegada da corte ao Rio de Janeiro, é que vão ser responsáveis por essas mudanças. As ordens régias de dois e sete de abril de 1808 determinam que fosse levado à Casa da Moeda o ouro que circulasse em barras para ser amoedado e instrui mudanças de rotinas nas casas de fundição. Em quatro de agosto, um decreto estabelece no Rio de Janeiro um fundo de 100 contos de réis para a permuta das barras de ouro existentes nas mãos de particulares (CARRARA, 2004: 16).

As principais normas são, todavia, instituídas nos decretos de primeiro de setembro e 12 de novembro, assim como no regulamento que

in loco das minas de ouro da Transilvânia em 1796. Em texto recente, ainda inédito, apresentado na 16th Annual Conference of the European Society for the History of Economic Thought em São Petersburgo, Rússia, em maio de 2012, exploro conexões entre estes documentos e os significados disso no âmbito da entrada de ideias de natureza cameralistas no pensamento econômico luso-brasileiro. 
acompanhava este último, com data de oito de novembro ${ }^{24}$. O primeiro desses decretos dispõe assim que "passados três meses depois da publicação desse meu alvará, não será o ouro em pó considerado como moeda, nem como tal poderá correr, mas somente como gênero, que somente poderá vender nas casas de fundição" 25 .É interessante verificar, não obstante, os termos em que a legislação se apresenta. Ratifica-se a consciência da decadência das Minas logo antes mesmo de se expor o interesse por criar condições para restringir a fuga da tributação, nos termos em que a medida foi originalmente proposta no século XVIII. Lê-se aí:"tendo consideração ao estado de decadência, em que se acham todas as minas de ouro do Estado do Brasil, e ao abuso, que se faz, extraviando-se a maior parte do ouro, que nelas se extrai, com gravíssimos prejuízos de minha real fazenda, e dos interesses de meus fieis vassalos, que se dão a esse gênero de indústria" ${ }^{26}$. E segue informando que não permitem as "atuais circunstâncias" colocar em prática as "saudáveis providências" previstas no alvará de 1803, mas delimitando um plano mais restrito que logrou finalmente alguma efetividade. Passavam a circular em Minas, a partir de então, as moedas de ouro, prata e cobre correntes nas capitanias litorâneas, assim como letras impressas, assinadas pelos intendentes e tesoureiros das casas de fundição e com valor de moeda corrente aos pagamentos à real fazenda. A introdução de um volume de numerário que fosse bastante à permuta não tinha quantitativos pré-definidos, devendo se fazer em função das necessidades específicas que fossem se verificando em cada parte, mas se ancorando especialmente na entrada de pesos espanhóis marcados com o cunho das armas reais, uma vez que não cabem "nas forças das Casas da Moeda do estado do Brasil recunhar as moedas estrangeiras com a prontidão, que convém, e atendendo à precisão, que há, de moeda de prata na capitania de Minas Gerais"27.

O alvará de 12 de outubro do mesmo ano se dispunha a "atalhar todos os obstáculos, que se possam oferecer" à "pronta, fácil execução"

24 Trata-se, este último, do "Regulamento provisional para o troco do ouro em pó na capitania de Minas Gerais".

25 Alvará de $1^{\circ}$ de setembro de 1808, sobre a "Circulação da Moeda de Ouro, Prata, e Cobre em todas as Capitanias; prohibindo que o Ouro em pó".

26 Idem.

27 Idem. 
do regulado do mês anterior, e descrevia assim as condições específicas de efetivação dos processos de permuta ou do regulamento para a feitura dos bilhetes impressos destinados a fazer troco ao ouro em pó. Não obstante, também reforma uma entrada na lei anterior, de setembro, que permitia a circulação de moedas espanholas de prata, não marcadas na capitania, assim como a saída daquelas marcadas com o cunho real que estavam a ser introduzidas ali. Ao que nos parece, o montante de moeda de prata introduzida não seria mesmo suficiente para as permutas, o que dava importância maior ao controle da saída dessas moedas da capitania, mas também, e especialmente, fazia com que o recurso aos bilhetes impressos fosse obviamente a solução mais utilizada. Faria acompanhar-se tal procedimento de espaço muito mais amplo à fraude, e a isso, tanto Raimundo José de Cunha Matos, em sua Corografia Histórica da Província de Minas Gerais de 1837, como antes dele, o já referido Wilhelm Ludwig von Eschwege, o Barão de Eschwege, fariam menção. Comenta o segundo:

Foi este alvará que muito prejuízo tem causado a Real Fazenda, não só por ter aberto maior caminho ao extravio mas também pela perda que se sofria nos trocos, e nos imensos bilhetes falsos, que logo foram introduzidos. As perdas nos trocos importam desde 1809 até 1814 em quatorze contos de reis que até agora será dobrado (RAPM, 1901:754).

A leitura da recorrência de um único tema na documentação relativa à Junta da Real Fazenda nas Minas - a proibição da circulação de ouro em pó e assuntos correlatos -, pode ser estendida a outras tantas questões que não podem aqui ser exploradas, mas que encontram subsídios para tanto na documentação apontada ao longo do artigo. A questão específica do contrabando e das forças militares na capitania, com a contraparte do peso disso nas despesas da fazenda, as Casas de Fundição e a redução de sua utilidade ao longo do tempo, as impressões sobre o comércio interno e externo da capitania em conexão aos contratos dos direitos das passagens e entradas, são alguns desses temas. Ou ainda, com menos destaque, mas com importância crescente nas deliberações no século XIX, os temas da educação pública, da construção de estradas, da infraestrutura a elas associadas e dos transportes em geral etc. 


\section{Considerações finais}

A recorrência temática na diversificada documentação analisada acima sugere um traço da dinâmica administrativa, mas também é uma porta de entrada à compreensão de impedimentos de ordem variada à resolução imediata dos problemas, uma vez que estes respondem tanto às limitações ou dificuldades na implementação em si das medidas quanto às decorrências diretas do conflito de interesses localmente constituídos. Este último aspecto, por exemplo, não pode ser mais bem apresentado por nenhuma outra temática que não a própria arrematação dos contratos régios na capitania. A arrematação ou a cobrança das dívidas acumuladas pelos contratos é tópico principal de grande parte dos pareceres da Junta da Real Fazenda por toda a segunda metade do século XVIII e início do século XIX. O tema que vem mesmo merecendo destaque da historiografia econômica na leitura específica da posição das figuras dos contratadores nas teias econômicas e sociais de então, mas ainda com pouco reflexo na investigação específica do órgão que a partir da criação do Erário Régio passaria a responder pelas arrematações dos contratos nas áreas coloniais são as Juntas da Fazenda.

Mais do que isso, entretanto, o que nos parece fundamental é a percepção de que o problema da efetiva abolição da circulação de ouro em pó - desde há muito efetivamente diagnosticado como um dos problemas centrais à administração das finanças na capitania, seja por conta do favorecimento aos descaminhos do ouro ou pelos entraves ao próprio desenvolvimento econômico em geral e ao giro do comércio em particular -, uma vez que implicava em investimento de grande monta por parte da administração central para se proceder efetivamente a permuta do ouro em pó que circulava como moeda por moeda metálica, fazia com que a solução do problema fosse de todo incompatível com o ordenamento colonial. A perspectiva da extração de recursos permaneceu sendo, até o limite do possível, a função precípua de todo o edifício colonial, e este princípio nunca deixou de ser observado pela administração central. Dessa forma, é interessante perceber como, mesmo ante amplas transformações nas conjunturas, o problema foi recorrentemente apresentado, e teve sua possível solução postergada repetidas vezes.

Por conta de todos os elementos ressaltados é que se destaca aqui, mais uma vez, a importância do estudo desse organismo, as Juntas da 
Fazenda, de forma necessariamente articulada à administração central das finanças do império, representada pelo Erário Régio, como um passo elementar para se avançar na compreensão do contexto de crise que enreda o império colonial português em fins do século XVIII e da própria forma e conteúdo das reflexões econômicas de então.

\section{Referências bibliográficas}

\section{Fontes primárias}

\section{Arquivo Histórico do Tribunal de Contas - Lisboa}

AHTC, Erário Régio, livro 461.

AHTC, Erário Régio, Livro 4066.

AHTC, Erário Régio, livro 4068.

AHTC, Erário Régio, Livro 4070.

\section{Arquivo Histórico Ultramarino - Lisboa}

AHU, Minas Gerais, cx.101, doc. 37.

\section{Revista do Arquivo Público Mineiro}

“1791 - Ponderações da Junta da Fazenda sobre os meios de se ressarcir o prejuízo da Real Fazenda com a arrecadação do quinto do ouro". RAPM, Belo Horizonte, ano 6 (1901).

"Bando lançado em o a Rayal de S. Pedro de Alcântara e Almas do Jacuhi para permuta do ouro em pó ou cunhado", RAPM, Belo Horizonte, ano 6 (1901).

"Exposição do Governador D. Rodrigo José de Meneses sobre o estado de decadência da capitania de Minas-Geraes e dos meios para remedia-lo", RAPM, Belo Horizonte, ano 2 (1897).

“Minas e quintos do ouro", RAPM, Belo Horizonte, ano 6 (1901).

"Notícias e Reflexões Estadisticas da Provincia de Minas Geraes por Guilherme, Barão de Eschewege", RAPM, Belo Horizonte, ano 6 (1901).

\section{Outras obras}

Coelho, José João Teixeira. Instrução para o governo da capitania de Minas Gerais. Belo Horizonte: Fundação João Pinheiro / Centro de Estudos Históricos e Culturais, 1994.

Silva, Antonio Delgado da. "Decreto Régio de 12 de junho de 1779" in Supplemento à Colleç̧ão de Legislação Portuguesa do Desembargador Antonio Delgado da Silva pelo mesmo. Ano de 1763 a 1790. Lisboa:Typ. de Luiz Correa da Cunha, 1844.

Vasconcellos, Diogo Pereira Ribeiro de. Breve descrição geografica, fisica e politica da Capitania de Minas Gerais. Belo Horizonte: Fundação João Pinheiro / Centro de Estudos Históricos e Culturais, 1994. 


\section{Referências}

BOSCHI, Caio César. "Administração e administradores no Brasil pombalino: os governadores da capitania de Minas Gerais”. Tempo. Rio de Janeiro, 2002(13): 77-109.

CARDOSO, José Luís; CUNHA, Alexandre Mendes. Discurso econômico e política colonial no Império Luso-Brasileiro (1750-1808). Tempo. Revista do Departamento de História da UFF, v. 17, n.31: 65-88, 2012a.

. Enlightened reforms and economic discourse in the Portuguese-Brazilian Empire (1750-1808). History of Political Economy, 44(4), 2012b.

CARRARA, Angelo Alves. "Mineração, produção rural e espaços urbanos em Minas Gerais, 1808-1835" in Anais do XII Seminário sobre a Economia Mineira. Belo Horizonte: Cedeplar/UFMG, 2006.

.A Real Fazenda de Minas Gerais; guia de pesquisa da Coleção Casa dos Contos de Ouro Preto (Instrumentos de Pesquisa, vol. 2). Ouro Preto: UFOP, 2004.

A Real Fazenda de Minas Gerais: guia de pesquisa da Coleção Casa dos Contos de Ouro Preto - Volume 2. Ouro Preto: UFOP, 2004.

. Minas e Currais: Produção Rural e Mercado Interno de Minas Gerais 16741807. Juiz de Fora: Editora UFJF, 2007.

. Receitas e despesas da Real Fazenda no Brasil - século XVIII. Juiz de Fora: Editora UFJF, 2009.

COSTA, Leonor Freire; ROCHA, Maria Manuela; SOUZA, Rita Martins de. "O ouro cruza o Atlântico" in RAPM, Belo Horizonte (41) 2005

CUNHA, Alexandre Mendes. "Da Junta da Real Fazenda à Tesouraria Provincial: a administração das finanças em Minas Gerais entre os séculos XVIII e XIX” in Venâncio, Renato; Gonçalves, Andréa Lisly e Chaves, Cláudia Maria das Graças (Orgs.). Administrando Impérios: Portugal e Brasil nos séculos XVIII e XIX. Belo Horizonte: Fino Traço Editora, 2012.

. Minas Gerais, da capitania à província: elites políticas e a administração da fazenda em um espaço em transformação. Niterói: UFF, 2007 (Tese de Doutorado em História).

Police Science and Cameralism in Portuguese Enlightened Reformism: economic ideas and the administration of the State during the second half of the 18th century. e-Journal of Portuguese History, v. 8, 2010.

FIGUEIREDO, Luciano Raposo de Almeida. "Derrama e política fiscal ilustrada". RAPM, Belo Horizonte (41) 2005.

Revoltas, fiscalidade e identidade colonial na América portuguesa: Rio de Janeiro, Bahia e Minas Gerais, 1640-1761. São Paulo: FFLCH/USP, 1996. (Tese de Doutorado em História)

GODINHO,Vitorino Magalhães. "Finanças públicas e estrutura do Estado" in Ensaios (II - Sobre História de Portugal). 2. ed rev. Lisboa: Sá da Costa, 1968.

GUIMARÃES, Carlos Gabriel."O rendimento da capitania das Minas Gerais no período 1795-1800: uma comparação com as capitanias do Rio de Janeiro, Bahia,

\section{4 | Alexandre Mendes Cunha}


Pernambuco"in Anais do XII Seminário sobre a Economia Mineira. Belo Horizonte: Cedeplar/UFMG, 2006.

IGLÉSIAS, Francisco. "Minas e a imposição do Estado no Brasil". Revista da História. São Paulo 50 (100), 1974.

MAXWELL, Kenneth. A devassa da devassa: a inconfidência mineira: Brasil-Portugal 17501808. 5. ed. São Paulo: Paz e Terra, 2001 [ed. original 1973].

Mello e Souza, Laura de. Desclassificados do Ouro: a pobreza mineira no século XVIII. Rio de Janeiro: Graal, 1982.

MELLO e SOUZA, Laura de. O Sol e a Sombra: política e administração na América portuguesa do século XVIII. São Paulo: Companhia das Letras, 2006.

MOREIRA, Alzira Teixeira Leite. Inventário do Fundo Geral do Erário Régio: Arquivo do Tribunal de Contas. Lisboa:Tip. Minerva do Comércio, 1977.

NOVAIS, Fernando A. Portugal e Brasil na crise do antigo sistema colonial (1777-1808). São Paulo: HUCITEC, 1979.

PAQUETTE, Gabriel B. (org.). Enlightened reform in Southern Europe and its atlantic colonies, c. 1750-1830. Farnham: Ashgate, 2009.

Enlightenment, governance and reform in Spain and its empire, 1759-1808. Basingstoke/Nova York: Palgrave Macmillan, 2008.

PAUlA, João Antonio de. Raízes da modernidade em Minas Gerais. Belo Horizonte: Autêntica, 2000.

RUSSELL-WOOD,A.J.R. Um mundo em movimento: os portugueses na África, Ásia e América (1415-1808). Algés: Difel, 1998 [ed. original 1992].

SALGADO, Graça (coord.), Fiscais e Meirinhos: a administração no Brasil colonial. Rio de Janeiro: Nova Fronteira; Brasília: INL, 1985.

SERRÃO, Joel (dir.). "Contos" [verbete] in Dicionário de história de Portugal. Porto: Livraria Figueirinhas, 1985.

. "O quadro econômico" in José Mattoso (dir.), História de Portugal [Quarto volume: O Antigo Regime (1620-1807) - ed. Acadêmica]. Lisboa: Editorial Estampa, 1998.

. "O quadro econômico" in Mattoso, José (dir.). História de Portugal [Quarto volume: O Antigo Regime (1620-1807) - ed. acadêmica], Lisboa, Editorial Estampa, 1998.

SIDERI, Sandro. Comércio e Poder, colonialismo informal nas relações anglo-portuguesas. Lisboa: Cosmos, 1978 [ed. original 1970].

SUBTIL, José. “Os poderes do centro: Governo e administração" in José MatToso (dir.), História de Portugal [Quarto volume: O Antigo Regime (1620-1807) - ed. acadêmica]. Lisboa: Editorial Estampa, 1998. 
